\begin{tabular}{c} 
Volume and Issues Obtainable at Center for Sustainability Research and Consultancy \\
Journal of Business and Social Review in Emerging Economies \\
ISSN: 2519-089X (E): 2519-0326 \\
Volume 6: No. 3, 2020 \\
CSRᄃ \\
Journal homepage: www.publishing.globalcsrc.org/jbsee \\
\hline
\end{tabular}

\title{
Fear Destroys the Ability to Trust: Impact on Employee Engagement during Structural Change in Telecommunication Sector of Pakistan
}

\author{
${ }^{1}$ Farzana Akmal Memon, ${ }^{2}$ Sobia Shafaq Shah, ${ }^{3}$ ImamUddin Khoso \\ ${ }^{1,2 \& 3}$ University of Sindh, Jamshoro, farzanamemon7@gmail.com
}

\begin{tabular}{l}
\hline ARTICLE DETAILS \\
\hline History \\
Revised format: August 2020 \\
Available Online: September \\
2020 \\
\hline Keywords \\
Trust in leadership, Fear of \\
Change, Employee's \\
Engagement with change, \\
Structural Change
\end{tabular}

JEL Classification

$M 0, M 1$

\begin{abstract}
Due to economic downturns and structural pressures, the telecommunication sector have frequently had to go through structural change to remain competitive. This could distract telecommunication sector away from focusing on trusting relationships leading towards failure in managing change. Present research fill this gap and aims to examine the effect of trust in leadership on employee's engagement during structural change. To provide additional insight, the present study used fear of change as a moderator between relationship of trust in leadership and employee engagement. Drawn from cross-sectional research design, a web-based survey was used to collect data from employees of telecommunication sector across all provinces of Pakistan that experienced structural change within their organization. A total of 447 responses were received. The study findings indicate that employee level of trust in leadership in change helped them to foster their engagement in change process. Additionally it was also supported that decrease in employee's fear of change enhances the effect of trust in leadership on employee's engagement during change.
\end{abstract}

(C) 2020 Center for Sustainability Research and Consultancy Pakistan under a Creative Commons Attribution-NonCommercial-ShareAlike 4.0

Corresponding author's email address: farzanamemon7@ gmail.com

Recommended citation: Memon, A. A., Shah, S. S. \& Khoso, I. U. (2020). Fear Destroys the Ability to Trust: Impact on Employee Engagement during Structural Change in Telecommunication Sector of Pakistan. Journal of Business and Social Review in Emerging Economies, 6(3), 1165-1175

\section{Introduction}

Organizational changes have become more prominent and recurrent in now-a-days (Bashori, 2016). Due to the competitive business environment, most organizations are experiencing change to survive (Hussain et al., 2018). Previous research indicated that organizations face difficulty in implementing change successfully due to the level of complexity associated with the organizational change (Islam, Furuoka, \& Idris, 2020).

Organizations face variety of changes, however structural change has marked the new digital realities of the twenty first century (Malik \& Garg, 2020). Structural changes tend to alter ways of doing things thus creating an uncertain environment where employees feel unsafe and cynical (Bakari, Hunjra, Jaros, \& Khoso, 2019). In order to implement change successfully and sustain the competitive edge in the market, organizations demand highly engaged workforce with lower levels of change related uncertainties and cordial leader member relations (Choi, 2011). Al-Jaber (2020) 
states that employees' engagement is seen as one of the most effective strategies in encouraging and preparing employees for change because without employees' engagement, effective change implementation will not be possible. Another concern during structural change is employees' trust in change leadership. As stated earlier, structural changes are prone to employee cynicism and uncertainty, thus may lead to negative behaviors (Bakari et al., 2019; Brown \& Cregan, 2008). However, role of trust in change leadership in this case is paramount which ultimately effect the employee attitude towards change and the degree of their willingness to support the change.

One more concern during change implementation processes is employees' fear of change which is again the outcome uncertainties involved in change process. Although much is known about role of employee trust in leadership in driving positive employee behaviors in organizational change, literature stills face scarcity of empirical evidence regarding interaction between trust and fear in driving change engagement. More specifically, this study addresses the significant gap in literature in outlining role of trust in leadership in developing employee engagement at various levels of employee fear of change. Next section briefly describes variables of the study and their relationship followed by methodology and results.

\section{Literature Review}

\subsection{Trust in Leadership}

Trust is defined as extent to which an individual is positive and ready to follow up on the words, activities, and choices of another individual (McAllister, 1995) Sanders, Schyns, Dietz, and Den Hartog (2006) indicated different dimensions with which trust has been measured like ability, benevolence, integrity, and predictability. Trust in leadership is actually the shared and mutual understanding among followers and leaders in such a way that vulnerabilities won't be misused and that the relationship is sheltered and respectful (Norman, 2006). Trust in leadership relies upon devotees' confidence and belief on the leader's activities and on positive result from their decision (Schoorman, Mayer, \& Davis, 2007) additionally trust also relies on faith in the leader's genuineness and the manner in which the person in question treats and thinks about devotees (Dirks \& Ferrin, 2002).

\subsection{Employee Engagement with Change}

The idea of engagement was introduced initially by Kahn (1990) but later other researchers have distinguished its different foci like work engagement (Bakker \& Demerouti, 2008), civic engagement (Skocpol \& Fiorina, 2004) school engagement, (Fredricks, Blumenfeld, Friedel, \& Paris, 2005), literacy engagement (Guthrie et al., 2004) and employee engagement (Schneider, Macey, Barbera, \& Young, 2010) Present study proposes that the engagement is target specific therefore there is need to test employee engagement with change at the time of structural changes.

Employee engagement emulates contribution of employee in business related exercises (Bakker \& Leiter, 2010) It reflects the mental bridling of employees to their job, which help them to express genuinely, psychologically, inwardly, and intellectually. Researchers defined employee's engagement specifically as a mental state wherein employees exhibit an elevated level of official identity and optional involvement in organization's objectives, mission and vision (Kahn, 1990).

\subsection{Fear of Change}

Fear reflects one's sense of nervousness relevant to threat posed by some external undesirable incident that has a potential to undermine one's safety and security (Strongin, 1987). Gray (1987) and Hebb (1946) defined fear of change as an employee's perception that the change is new and unfamiliar and cannot be relied upon due to uncertainties involved. The fear is triggered by the ambiguity regarding outcomes, the risk of losing valued position and the complications regarding altered status in the organizations (Piderit, 2000).

\section{Hypothesis Development}

\subsection{Employee's Trust in Leadership and Employee Engagement}

Previous research indicates that an atmosphere of trust in leadership prompts employees to take part in organizational processes because increase in trust ultimately results in positive behaviors and attitudes towards organization such as employee's commitment and employees work engagement (Dirks \& Ferrin, 2002). Trusting environment in the 
organization is a powerful motivator that elevates the degree of employee's participation and information sharing (Käser \& Miles, 2002). Moreover, it also fuels employee's performance (Dirks, 2000). Islam et al. (2020), recently indicated that during the time of uncertainty, the trusting environment can reduce the frailties and fears of employees and ultimately influences their engagement with the organization like, if the trust in leadership is high, employees presume sensible decisions from their leaders leading towards organization's stability. Employee's focus on their everyday work is associated with the high level of trust (Mayer \& Gavin, 2005) and eventually make employees feel assured that the "big picture" is taken care of which then finally multiply employee's engagement in the organization (Kahn, 1990) during uncertain time.

It is often proposed by researchers that leaders should build trusting relationship with employees that ultimately empower them to successfully manage (change) processes in the workplace (Judge, LePine, \& Rich, 2006). An efficient leader encourages an environment that creates a trusting relationship during mind boggling and unpleasant circumstances, (Li, Wang, \& Wang, 2019), which actually supports employees (Howarth \& Rafferty, 2009) and energies as a guide (Bass, Avolio, Jung, \& Berson, 2003).

Recent studies specified that trust in leadership develops employee's degree of work engagement during times of organizational change ( $\mathrm{Li}$ et al., 2019). Employing psychological contract theory can truly explain the relationship and bonding between leader and the follower/employees, which builds a psychological contract between them (Rousseau, 1995). In this way, a trust in this link which shapes a psychological contract upgrades the degree of employee's work engagement (McAllister, 1995). Islam et al. (2020), indicates that degree of employee engagement is dependent upon the level of trust in leadership that employees have in their leader. Based on prior theorizing (Chughtai \& Buckley, 2008) and (Kahn, 1990), trust towards leaders positively influence their levels of engagement. Hence, present study hypothesized:

\section{H1: During structural change, trust in leadership positively related to employee's engagement with change}

\subsection{Fear of Change as a Moderator}

Literature suggests that trust in leadership and employee engagement may have some boundary conditions. Literature indicates that in present business world, the demand for the structural change is high and so is the case for fear associated with that change. Fear of change is perhaps the most significant impulse behind employees distinction in their eagerness to trust their leaders (Bennett et al., 1998).

Weeks, Roberts, Chonko, and Jones (2004) used fear of change as a moderator between readiness to accept change and employees' performance such that impact of change readiness on employee performance was dependent upon employee level of fear and uncertainty. Higher levels of fear will deplete employees' willingness to perform better in new situations. From a psychoanalytic point of view, a key explanation that employees don't accept change is due to their fear of change where vulnerability, doubt and distrust in leadership is present because employees with fear of change feel a lack of control (Evans, 2001). He further indicated that fear of change is a true reason that people don't change as the fear may involve threat, anxiety and tension or loss of security. Senge and Kaeufer (2000) explained that change endeavors prompt fear specifically, structural changes raise doubt about long held convictions, mentalities, and routine methods of acting. Uncertainty and fear related with change can lead individual employees to cling to old patterns of conduct (De Vries \& Balazs, 1999). This is actually the fear of failure that eventually forms a fear of change and lastly the desire to stick to their status quo. With the above literature and Preacher and Hayes (2008) description of a moderator, employee's fear of change is modeled to moderate trust in leadership and employee's engagement relationship. More specifically, this study posits that during structural change if employees experience lower levels of fear of change, they would be more likely to trust in leadership and can have higher levels of engagement towards change. Similarly, employees with high fear of change will remark less trust in leadership and will not be likely to engage in their job during change. Therefore, present study hypothesized:

H2: During structural change, the relationship of trust in leadership and employee engagement is stronger when employee's fear of change is low rather than high. 


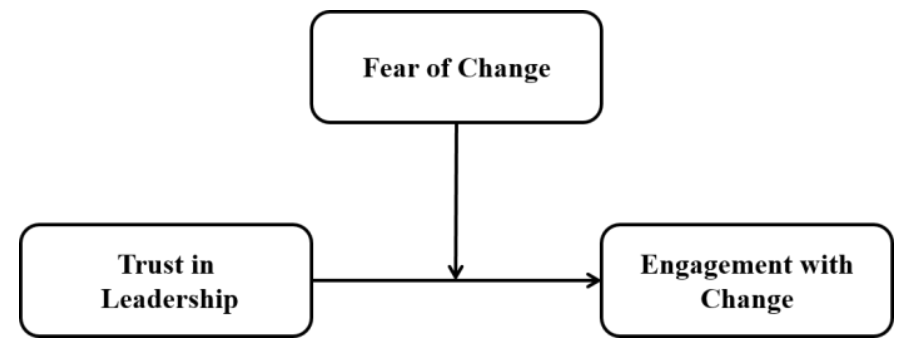

Figure 1: Conceptual framework

\section{Methodology}

\subsection{Procedure of Data Collection}

This study is conducted using the sample drawn from the telecommunication companies of Pakistan (PTCL, Mobilink, Ufone and Telenor) which were undergoing structural changes during the time of data collection. Using positivist approach, a cross sectional research design and Stratified random sampling technique were applied to collect data. 560 online questionnaires were emailed to employees after getting formal approval from respective head offices. The questionnaire included a cover letter that expressed objectives of the survey, ensured respondents for the confidentiality of their responses and that the participation was entirely voluntary. Out of 560 questionnaires, 447 questionnaires were received back (79\% response rate).

\subsection{Measures}

4.2.1 Trust in change leadership Scale was adapted from the work of Bouckenooghe, Devos, and van den Broeck (2009). The sample item include "Change management team fulfils its promises " Fear of change scale was adapted from the work of Weeks et al. (2004). The sample item include "I am fearful of change" and Employee's engagement with change scale was adapted from the work of Schaufeli, Bakker, and Salanova (2006). The sample item include "At my work, I feel that I am bursting with energy". Data of three constructs were collected using 7-point Likert scale of 'strongly disagree' to 'strongly agree'. For analyzing the data, first SPSS was used for preliminary analysis and for testing the validity reliability and significance and relevance of path coefficients the partial least square (PLS-SEM) approach was applied by using SMART PLS (Ringle, Wende, \& Becker, 2015)

\subsection{Demographic Details}

The majority of the respondents were male representing 73\%. Around 30\% employees responded from Mobilink, $21 \%$ from Telenor and Ufone and 27\% from PTCL. 29\% participants belong to Sindh province, 27\% from Punjab, $24 \%$ from Baluchistan and 20\% from Khyber-Pakhtunkhwa. In terms of education, high percent of respondents were master's degree holder representing $62 \%$ of sample, $32 \%$ were bachelor's degree holders, $5 \%$ holds doctorate degree. Employment tenure of $49 \%$ respondents were $2-5$ years, $31 \%$ were $6-10$ years, $12 \%$ are employed less than a year $7 \%$ were employed from 11-15 years and 0.7\% employees are in employment tenure of more than 15 years.

\section{Data Analysis}

To avoid the possible destructions in data analysis, the preliminary analysis was conducted (Hair, Black, Babin, \& Anderson, 2010). Present study has no missing values as online survey has reduced the missing data (Hair, Hult, Ringle, \& Sarstedt, 2017). Common method bias was not an issue in present study model. The multivariate normality test was conducted which indicated that the data was slightly non-normal as PLS-SEM is a non-parametric statistical method so continuing towards the analysis.

\subsection{Structural Equation Modeling}

In order to test hypothesis, structural equation modeling was used using two step approach of (Anderson \& Gerbing, 1988). Firstly, in a measurement model, all variables of study are subjected to assessment of their validity and reliability. Then comes testing of structural model, in which conceptual framework is transformed into structural model to assess path coefficients of the model and see whether there exist relationships as hypothesized or not.

\subsection{Measurement Model}

Table 1 indicates that the outer loadings are satisfactory as the same are greater than 0.50 hence establishes the indicator reliability (Hair et al., 2017). The values of composite reliability (CR) are higher than the recommended 
value of 0.7 hence indicate the establishment of internal consistency reliability (Hair, Black, Babin, Anderson, \& Tatham, 2006). Convergent validly is maintained in present study as the average variance extracted (AVE) values greater than 0.5 (Hair et al., 2006).

Table 1: Indicator Reliability, Composite Reliability and Convergent Validity

\begin{tabular}{llccc}
\hline Constructs & Items & $\begin{array}{c}\text { Outer } \\
\text { loading }\end{array}$ & $\begin{array}{c}\text { Composite } \\
\text { Reliability }\end{array}$ & $\begin{array}{c}\text { Average Variance } \\
\text { Extracted }\end{array}$ \\
\hline Employee's Engagement with change & EE1 & 0.747 & & \\
& EE2 & 0.910 & & \\
& EE3 & 0.876 & 0.932 & \\
& EE4 & 0.883 & & \\
& EE5 & 0.859 & & \\
\hline Employee's Trust in leadership & ET1 & 0.894 & & \\
& ET2 & 0.917 & & \\
& ET3 & 0.921 & 0.954 & \\
& ET4 & 0.919 & & \\
& ET5 & 0.831 & & \\
\hline Fear of Change & FOC1 & 0.618 & & \\
& FOC2 & 0.836 & \multirow{2}{*}{0.806} & \\
& FOC3 & 0.739 & & \\
& FOC4 & 0.651 & & \\
\end{tabular}

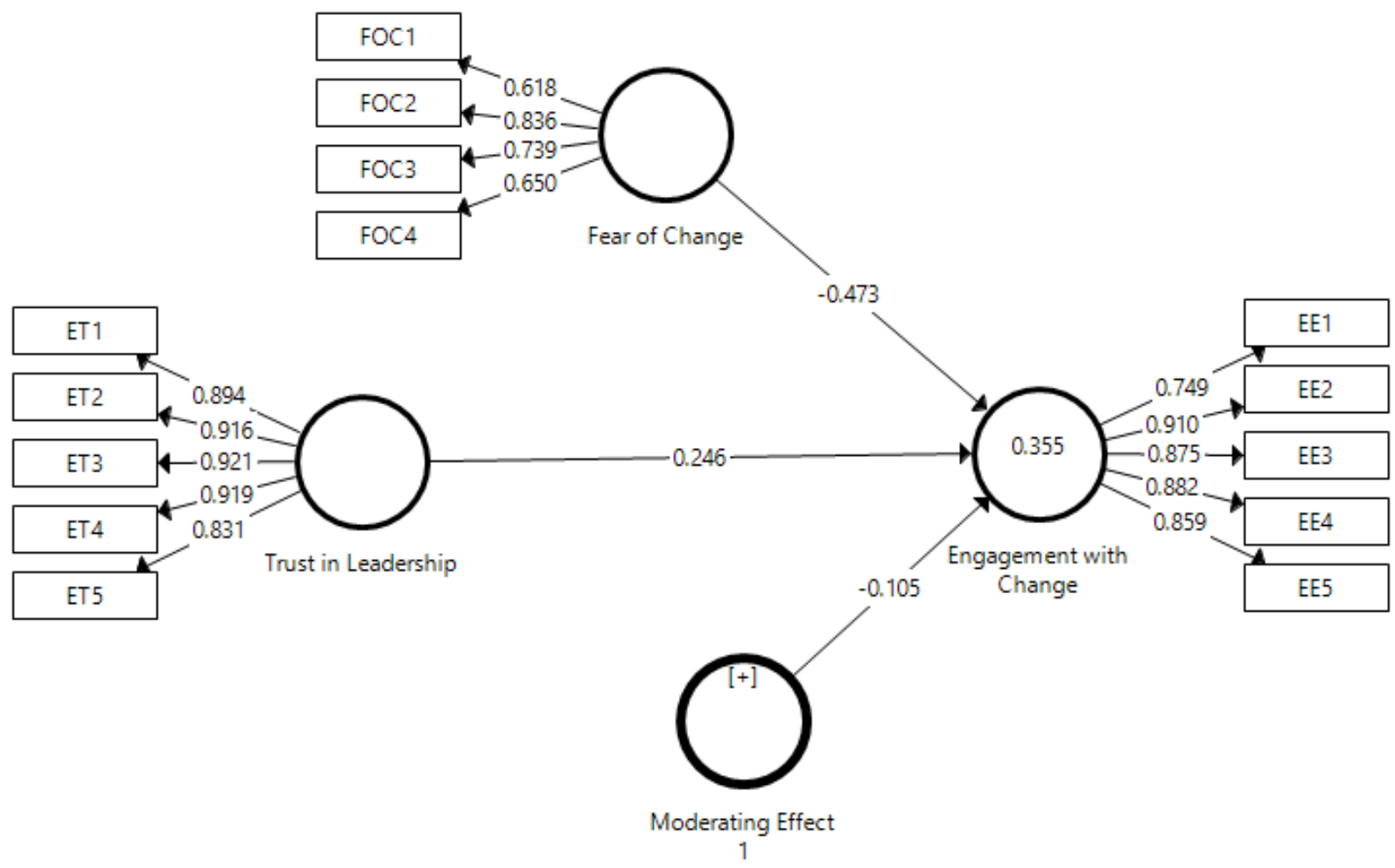

Figure 2: Outer Model SMART PLS

Present study following suggestion of Henseler, Ringle, and Sarstedt (2015) assess the discriminant validity in the form of HTMT ratio. Table 2 indicates that all the HTMT values are less than 0.85 henceforth ascertained discriminant validity (Henseler et al., 2015).

Table 2: Discriminant Validity (HTMT)

\begin{tabular}{lccc}
\hline & 1 & 2 & 3 \\
\hline Employee's Engagement & & & \\
Employee's Trust in & 0.365 & & \\
\hline
\end{tabular}




\begin{tabular}{lll}
\hline leadership & & \\
Fear of Change & 0.621 & 0.255 \\
\hline
\end{tabular}

\subsection{Structural Model}

After establishing reliability and validity in the measurement model, the succeeding stage is to analyze the structural model. Present study has employed bootstrapping method with 5000 resamples (Hair et al., 2017) using BiasCorrected and Accelerated (BCa) Bootstrap with one tailed with significance level is 0.05 . The bootstrapping result indicate that employee's trust in leadership is positively and significantly associated to employee's engagement with change $\beta=0.246, \mathrm{t}$-value $=5.796, \mathrm{p}<0.05$ (Hair et al., 2017) with $\mathrm{CI}[0.185,0.317]$ not overlapping the zero value in between (Preacher \& Hayes, 2008). Hence indicating the acceptance of H1. The relationship has strong effect size, F2= 0.362 (Wong, 2013). Present study provide the support that fear of change moderates the relationship between employee's trust in leadership and employee's engagement with change $\beta=-0.105$, t-value $=1.871$ and $p<0.05$ (Hair et al., 2017). Hence accepting and supporting H2. The significance level of the present study pertain to the coefficients is 0.05 (i.e., 95\% confidence level) so by employing 95\% bias-corrected bootstrap, CI of the interaction term's effect is $[-0.174,-0.135]$ indicating that confidence interval has not overlapped the zero value (Preacher \& Hayes, 2008) hence representing significant moderating effect of fear of change between employee's trust in leadership and employee's engagement with change. The interaction effect has small effect size $\mathrm{F}^{2}=0.031$, (Wong, 2013).

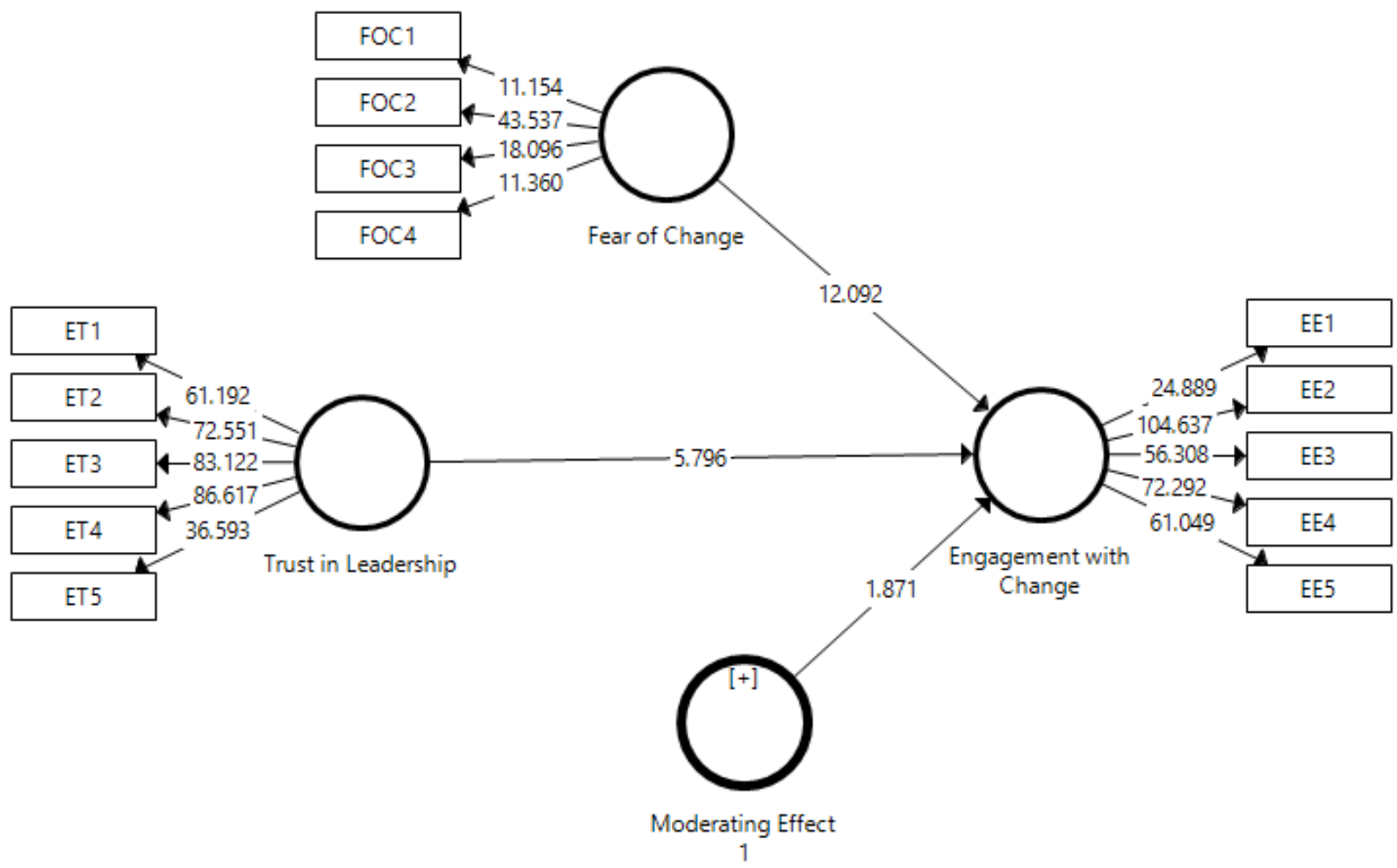

Figure 3: Inner Model - SMART PLS

Moderation effect is further explained in an interaction plot (Figure 4) which shows the buffering effect where fear of change reduces the impact of employee's trust in leadership on employee's engagement with change. In other words, presence of fear of change in individual would decrease employee's trust in leadership during change. More specifically, relationship between trust in leadership and employee engagement with changed in confounded by fear of change such that the relationship is only stronger when fear of change is lower rather than high. 


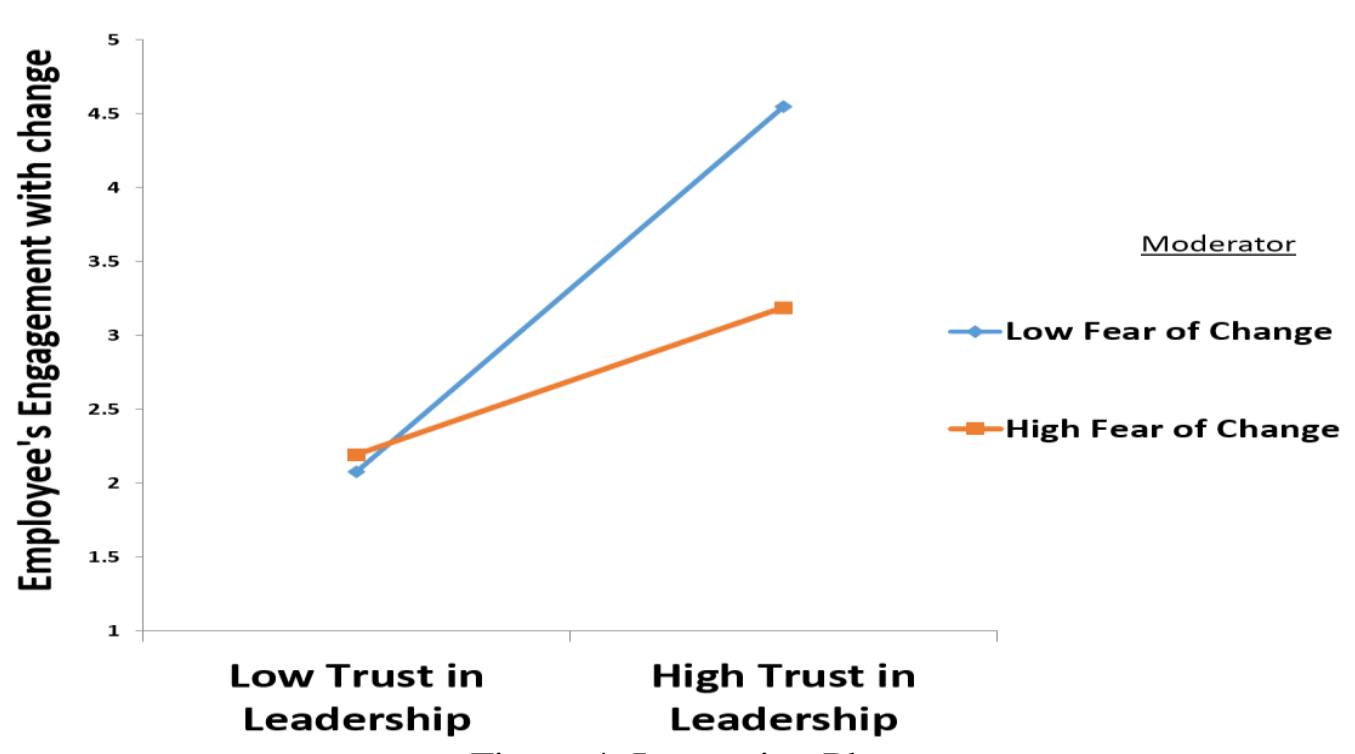

Figure 4: Interaction Plot

The present study model explains $35.5 \%$ of total variance in employee's engagement with change indicating that moderate level of R2 (Chin, 1998). The present study employed blindfolding procedure which reuse sample by omitting a part of a data matrix with omission distance 7 (Hair, Ringle, \& Sarstedt, 2013) that calculates the StoneGeisser's Q2 value (Geisser, 1975; Stone, 1974), which evaluates cross-validated predictive relevance of the PLS path model. The present study indicate the predictive relevance of the model as the Q2 value of endogenous variables is above zero, i.e. employee's engagement with change $=0.307$ (Henseler, Ringle, \& Sinkovics, 2009) demonstrating moderate level of predictive relevance (Hair, Sarstedt, Ringle, \& Gudergan, 2018). Present study following the suggestion of Shmueli, Ray, Estrada, and Chatla (2016) using PLS Predict check the model's out of sample predictive power of employee's engagement with change by using 10 folds and 10 repetitions. Table 3 indicates that all the errors of the PLS model of Key Endogenous Construct were lower than the LM model thus present study model has a strong predictive power (Shmueli et al., 2019)

Table 3: Predictive Power of Key Endogenous Construct - Employee’s Engagement

\begin{tabular}{lcccccc}
\hline & RMSE & MAE & RMSE & \multicolumn{1}{l}{ MAE } & RMSE & MAE \\
\hline EE1 & 1.203 & 0.934 & 1.307 & 1.075 & -0.104 & -0.141 \\
EE2 & 1.137 & 0.879 & 1.300 & 1.032 & -0.163 & -0.153 \\
EE4 & 1.154 & 0.890 & 1.266 & 1.012 & -0.113 & -0.123 \\
EE5 & 1.220 & 0.950 & 1.309 & 1.057 & -0.089 & -0.107 \\
EE3 & 1.024 & 0.806 & 1.150 & 0.969 & -0.126 & -0.163 \\
\hline
\end{tabular}

\section{Discussion}

Role of leaders is paramount in managing change however, leaders' effectiveness tend to depend on degree to which they enjoy trusting relationships with their employees. Leaders can only be effective when they become successful in gaining employees trust in them. This study has therefore indicated important confounding factor, that is, fear of change that plays very pivotal role in relationship between trust in leadership and employee change engagement.

Present research supported hypotheses such that employees trust in leader facilitated their engagement with change as the findings are in line with the literature indicating that trust in leadership between employee and leaders anticipated the employees' engagement with change. The previous researches likewise indicate that when employees experience higher level of trust in leaders, they are more likely to engaging themselves in work (Chughtai \& Buckley, 2008) ; (Schneider et al., 2010). In a similar vein, other research additionally claimed that when trust in leadership is high, employees can focus on their work, expanding their degrees of engagement (Mayer \& Gavin, 2005) with change. Present research findings are likewise reliable with the discoveries of Kahn (1990) to such an extent that more significant levels of trust in leadership add to higher employee's engagement (with change process). Most recent work 
of Islam et al. (2020) demonstrates that high degree of trust in leadership building will lead towards employee's engagement. Consequently, to improve the degree of employee's engagement with change, managers-especially those in a situation that is experiencing structural change-should give cautious consideration to the concept of trust in leadership as the stronger the employee's level of trust in leadership, the stronger their level of engagement with change process and eventually a successful change management process.

Another finding of the study that uncovers fear of change as a moderator between trust in leadership and employee engagement with change was also supported. This finding requires an understanding of experiencing fear of change. Like the exclamation, "if it isn't broken, don't fix it," is a sign of distrust in leadership that might cause employee's fear of change. Being acknowledged with the part, that fear plays in employee's engagement with change; mangers must take keen interest in understanding how fear demonstrates itself in the environment of the organization. Fear and trust in leadership are often related. When there is fear there will less trust in leadership. If trust in leadership need to be created than reducing fear is an important task.

\section{Practical Implications}

This study has greater implications for managers of structural changes such that they should not just be contented with cordial and trusting relationship with their employees as their change related behaviors will be dependent upon the factors in the content of the change rather than the aspects related to leaders (Walker, Armenakis, \& Bernerth, 2007). Ahmad and Cheng (2018) tested the role of leadership and change content in driving employee commitment to change. Although they found that transformational leadership which focusses on trusting relationship with leaders was found positively related to commitment to change. However, change related factors such as history of previous failures negatively impacted their commitment to change. our study has explained this process more profoundly and provided the specific evidence that despite the fact that trust in leadership drive positive employee behaviors, employee fear of change cannot be ignored. Therefore, managers need to be more vigilant and focus on the factors that create fears and uncertainties, which are most of the time unfounded and sometimes very real. With the structural changes, managers must divert their attention on fear of change as a priority and major matter in order to maintain the employee's confidence and trust that will ultimately lead to the success of change implementation because the vital means used by organizations during structural change is to foster a positive shift with respect to employee's trust. During structural change, employee's negative reactions and poor confidence can be reduced by removing the fear of change and effectually providing support as structural changes effects on the employee's trustworthiness, which can merely be managed by through listening and reducing employee's concerns and fear regarding the change in order to form a basis for the successful implementation of the change.

\section{Conclusion}

In recent decade organizational change has been remarkably, broaden after the consequences of globalization and evoking market competition. Employees who are facing the change within organization should be considered as a subject of the change rather than the object as employee enjoy and adore working in such organizations where their leaders create trusting relationship with them during change. As Levering (1995) putting emphasis on the quality of relationship indicates that those organizations are accepted as a great place to work where trusting relationship between leader and employee is maintained which in turn can eventually contribute to positive employee's engagement with change. Furthermore, the fear of change moderates this relationship as Employee facing fear of change will look closely for symbols of distrust in leadership consequently fear of change weaken the relationship between trust in leadership and employee's engagement with change. Present study is a significant contribution towards the literature of trust and engagement in change context as this study has collected data from a versatile sample of telecommunication sector undergoing massive changes and has utilized classical planned change management theory.

\section{References}

Ahmad, A. B., \& Cheng, Z. (2018). The role of change content, context, process, and leadership in understanding employees' commitment to change: The case of public organizations in kurdistan region of iraq. Public Personnel Management, 47(2), 195-216. doi:10.1177/0091026017753645 
Al-Jaber, M. A. (2020). Dimensions of Internal Communication for Organisation Engagement: The Role of CoWorker Trust. Brunel University London,

Anderson, J. C., \& Gerbing, D. W. (1988). Structural equation modeling in practice: A review and recommended twostep approach. Psychological bulletin, 103(3), 411-423.

Bakari, H., Hunjra, A. I., Jaros, S., \& Khoso, I. (2019). Moderating role of cynicism about organizational change between authentic leadership and commitment to change in Pakistani public sector hospitals. Leadership in Health Services.

Bakker, A. B., \& Demerouti, E. (2008). Towards a model of work engagement. Career development international.

Bakker, A. B., \& Leiter, M. P. (2010). Where to go from here: Integration and future research on work engagement. Work engagement: A handbook of essential theory and research, 181-196.

Bashori, B. (2016). MANAJEMEN PERUBAHAN KURIKULUM KTSP 2006 KE-KURIKULUM 2013 DI SMA NEGERI 1 KEDIRI. Jurnal Penelitian LPPM (Lembaga Penelitian dan Pengabdian kepada Masyarakat) IKIP PGRI MADIUN, 4(2), 94-106.

Bass, B. M., Avolio, B. J., Jung, D. I., \& Berson, Y. (2003). Predicting unit performance by assessing transformational and transactional leadership. Journal of Applied Psychology, 88(2), 207.

Bouckenooghe, D., Devos, G., \& van den Broeck, H. (2009). Organizational Change Questionnaire-Climate of Change, Processes, and Readiness: development of a new instrument. J Psychol, 143(6), 559-599. doi:10.1080/00223980903218216

Brown, M., \& Cregan, C. (2008). Organizational change cynicism: The role of employee involvement. Human Resource Management, 47(4), 667-686.

Chin, W. W. (1998). Issues and Opinion on Structural Equation Modeling

Choi, M. (2011). Employees' attitudes toward organizational change: A literature review. Human Resource Management, 50(4), 479-500. doi:10.1002/hrm.20434

Chughtai, A. A., \& Buckley, F. (2008). Work engagement and its relationship with state and trait trust: A conceptual analysis. Journal of Behavioral and Applied Management, 10(1), 47.

De Vries, M. F. K., \& Balazs, K. (1999). Transforming the mind-set of the organization: A clinical perspective. Administration \& Society, 30(6), 640-675.

Dirks, K. T. (2000). Trust in leadership and team performance: Evidence from NCAA basketball. Journal of Applied Psychology, 85(6), 1004.

Dirks, K. T., \& Ferrin, D. L. (2002). Trust in leadership: Meta-analytic findings and implications for research and practice. Journal of Applied Psychology, 87(4), 611.

Evans, E. A. (2001). Executive commentary. Academy of Management Perspectives, 15(4), 94-95.

Fredricks, J. A., Blumenfeld, P., Friedel, J., \& Paris, A. (2005). School engagement. In What do children need to flourish? (pp. 305-321): Springer.

Geisser, S. (1975). The predictive sample reuse method with applications. Journal of the American statistical Association, 70(350), 320-328.

Gray, J. A. (1987). The psychology of fear and stress (Vol. 5): CUP Archive.

Guthrie, J. T., Wigfield, A., Barbosa, P., Perencevich, K. C., Taboada, A., Davis, M. H., .. . Tonks, S. (2004). Increasing reading comprehension and engagement through concept-oriented reading instruction. Journal of educational psychology, 96(3), 403.

Hair, J. F., Black, W. C., Babin, B. J., \& Anderson, R. E. (2010). Multivariate data analysis (7th ed.). New Jersey: Pearson Prentice Hall.

Hair, J. F., Black, W. C., Babin, B. J., Anderson, R. E., \& Tatham, R. L. (2006). Multivariate data analysis (6 ed.). New Jersey:: Pearson Education.

Hair, J. F., Hult, G. T. M., Ringle, C. M., \& Sarstedt, M. (2017). A primer on partial least squares structural equation modeling (PLS-SEM) (Vol. null): Sage.

Hair, J. F., Ringle, C. M., \& Sarstedt, M. (2013). Partial least squares structural equation modeling: Rigorous applications, better results and higher acceptance. Long Range Planning, 46(1-2), 1-12. doi:10.1016/j.lrp.2013.01.001

Hair, J. F., Sarstedt, M., Ringle, C. M., \& Gudergan, S. P. (2018). Advanced issues in partial least squares structural equation modeling (PLS-SEM) (Vol. null).

Hebb, D. O. (1946). On the nature of fear. Psychological review, 53(5), 259. 
Henseler, J., Ringle, C. M., \& Sarstedt, M. (2015). A new criterion for assessing discriminant validity in variancebased structural equation modeling. Journal of the Academy of Marketing Science, 43(1), 115-135. doi:10.1007/s 11747-014-0403-8

Henseler, J., Ringle, C. M., \& Sinkovics, R. R. (2009). The use of partial least squares path modeling in international marketing. In New challenges to international marketing: Emerald Group Publishing Limited.

Howarth, M. D., \& Rafferty, A. E. (2009). TRANSFORMATIONAL LEADERSHIP AND ORGANIZATIONAL CHANGE: THE IMPACT OF VISION CONTENT AND DELIVERY. Paper presented at the Academy of Management Proceedings.

Hussain, S. T., Lei, S., Akram, T., Haider, M. J., Hussain, S. H., \& Ali, M. (2018). Kurt Lewin's change model: A critical review of the role of leadership and employee involvement in organizational change. Journal of Innovation \& Knowledge, 3(3), 123-127. doi:10.1016/j.jik.2016.07.002

Islam, M. N., Furuoka, F., \& Idris, A. (2020). The impact of trust in leadership on organizational transformation. Global Business and Organizational Excellence, 39(4), 25-34.

Judge, T. A., LePine, J. A., \& Rich, B. L. (2006). Loving yourself abundantly: relationship of the narcissistic personality to self-and other perceptions of workplace deviance, leadership, and task and contextual performance. Journal of Applied Psychology, 91(4), 762.

Kahn, W. A. (1990). Psychological conditions of personal engagement and disengagement at work. Academy of management journal, 33(4), 692-724.

Käser, P. A., \& Miles, R. E. (2002). Understanding knowledge activists' successes and failures. Long Range Planning, 35(1), 9-28.

Levering, R. (1995). Great place to work: Random House Value Publishing.

Li, X., Wang, S. S., \& Wang, X. (2019). Trust and IPO underpricing. Journal of Corporate Finance, 56, $224-248$.

Malik, P., \& Garg, P. (2020). Learning organization and work engagement: The mediating role of employee resilience. The International Journal of Human Resource Management, 31(8), 1071-1094.

Mayer, R. C., \& Gavin, M. B. (2005). Trust in management and performance: Who minds the shop while the employees watch the boss? Academy of management journal, 48(5), 874-888.

McAllister, D. J. (1995). Affect-and cognition-based trust as foundations for interpersonal cooperation in organizations. Academy of management journal, 38(1), 24-59.

Norman, S. M. (2006). The role of trust: Implications for psychological capital and authentic leadership: The University of Nebraska-Lincoln.

Piderit, S. K. (2000). Rethinking resistance and recognizing ambivalence: A multidimensional view of attitudes toward an organizational change. Academy of Management Review, 25(4), 783-794.

Preacher, K. J., \& Hayes, A. F. (2008). Asymptotic and resampling strategies for assessing and comparing indirect effects in multiple mediator models. Behavior Research Methods, 40(3), 879-891.

Ringle, C. M., Wende, S., \& Becker, J. M. (2015). SmartPLS 3 (Vol. null).

Rousseau, D. (1995). Psychological contracts in organizations: Understanding written and unwritten agreements: Sage publications.

Sanders, K., Schyns, B., Dietz, G., \& Den Hartog, D. N. (2006). Measuring trust inside organisations. Personnel Review.

Schaufeli, W. B., Bakker, A. B., \& Salanova, M. (2006). The measurement of work engagement with a short questionnaire: A cross-national study. Educational and Psychological Measurement, 66(4), 701-716.

Schneider, B., Macey, W. H., Barbera, K. M., \& Young, S. A. (2010). The role of employee trust in understanding employee engagement. Handbook of employee engagement: Perspectives, issues, research and practice, 159173.

Schoorman, F. D., Mayer, R. C., \& Davis, J. H. (2007). An integrative model of organizational trust: Past, present, and future. In: Academy of Management Briarcliff Manor, NY 10510.

Senge, P. M., \& Kaeufer, K. H. (2000). Creating change. Executive excellence, 17(10), 4-4.

Shmueli, G., Ray, S., Estrada, J. M. V., \& Chatla, S. B. (2016). The elephant in the room: Predictive performance of PLS models. Journal of Business Research, 69(10), 4552-4564.

Shmueli, G., Sarstedt, M., Hair, J. F., Cheah, J.-H., Ting, H., Vaithilingam, S., \& Ringle, C. M. (2019). Predictive model assessment in PLS-SEM: guidelines for using PLSpredict. European Journal of Marketing.

Skocpol, T., \& Fiorina, M. P. (2004). Civic engagement in American democracy: Brookings Institution Press. 
Stone, M. (1974). Cross-validatory choice and assessment of statistical predictions. Journal of the Royal Statistical Society: Series B (Methodological), 36(2), 111-133.

Strongin, T. S. (1987). A historical review of the fear of flying among aircrewmen. Aviation, Space, and Environmental Medicine, 58(3), 263-267.

Walker, H. J., Armenakis, A. A., \& Bernerth, J. B. (2007). Factors influencing organizational change efforts: An integrative investigation of change content, context, process and individual differences. Journal of Organizational Change Management, 20(6), 761-773. doi:10.1108/09534810710831000

Weeks, W. A., Roberts, J., Chonko, L. B., \& Jones, E. (2004). Organizational readiness for change, individual fear of change, and sales manager performance: An empirical investigation. Journal of Personal Selling \& Sales Management, 24(1), 7-17.

Wong, K. K.-K. (2013). Partial least squares structural equation modeling (PLS-SEM) techniques using SmartPLS. Marketing Bulletin, 24(1), 1-32. 